\title{
THE ACQUISITION OF PRE-TONIC VOWELS IN BRAZILIAN PORTUGUESE
}

\author{
Graziela Pigatto BOHN* \\ Raquel Santana SANTOS ${ }^{* *}$
}

- ABSTRACT: This article discusses acquisition of pre-tonic vowels in Brazilian Portuguese by 3 monolingual children acquiring the paulista dialect, aged between 1;4 and 3;5, and its relation to the acquisition of stressed vowels. Based on Miranda (2013), we start out from the supposition that the acquisition of pre-tonic vowels is subject to the instability of this position, and segments affected by phonological processes take longer to be acquired. The children's productions show that high pre-tonic vowels are acquired in contrast with mid vowels, (/i,o/ and /e,u/), and that the pre-tonic /o/ is acquired before /e/. We analyse these results based on Contrastive Hierarchy Theory (DRESHER, 2009), according to which the lexical representation of segments is specific to each language and only contrastive and active features must be present in the representation. We propose that the acquisition of pre-tonic vowels follows the Principle of Maximum Contrast: because of the instability found in this position, segments must be maximally contrastive; that is, they must contrast in place and height. The pre-tonic /e/, being more unstable (cf. CALLOU; MORAES; LEITE, 2002; VIEGAS, 2001; YACOVENCO, 1993), is the last one to be acquired, bringing with it the pretonic /u/.

- KEYWORDS: Phonological acquisition. Phonological contrast. Pretonic vowel.

\section{Introduction}

The goal of this study is to discuss the acquisition of vowels in the pre-tonic position in Brazilian Portuguese (BP). Previous studies (RANGEL, 2002; BONILHA, 2004; VOGELEY, 2011) suggest that vowel systems emerge as proposed by Jakobson (1968[1941]): first low vowels, followed by high and then mid vowels. These proposals assume that features and their organization are universal, leading to predictions that do not always correspond to facts. For example, if features are innate and their hierarchical organization and acquisition pattern are universal, (low $>$ high $>$ mid), then the prediction

\footnotetext{
Catholic University of Santos (UNISANTOS), Santos - São Paulo - Brazil. Center for Education and Communication Sciences.grazielabohn@gmail.com

*** University of São Paulo (USP), São Paulo - São Paulo - Brazil. Department of Linguistics. raquelss@usp.br
} 
of a theory such as Feature Geometry (CLEMENTS; HUME, 1995), for example, is that the mid front and back vowels emerge at the same time. As facts do not always corroborate this prediction, a lot of analyzes assume sub-stages to capture the asymmetries found in the data. Furthermore, it is also possible to find in the data not only asymmetries but different paths of acquisition, and this type of result calls into question the description given by theories that argue for a universal pattern of acquisition. Most studies of vowel acquisition in BP either focus only on the acquisition of stressed vowels, or consider all word positions and analyze stress as an independent variable that may (or may not) affect the acquisition process (RANGEL, 2002; MIRANDA; MATZENAUER, 2009). Conversely, Bohn (2015) analyzes the acquisition of stressed and pre-tonic vowels separately and finds that the order of acquisition in these two positions is different. Following Miranda (2013), Bohn argues that the order of acquisition of mid vowels is different in the pre-tonic position because these vowels behave differently in this position, and children are sensitive to this difference. Based on studies of vowel harmony affecting pre-tonic vowels in adult speech, which indicate that this process affects only the pre-tonic /e/ (CALLOU; MORAES; LEITE, 2002; YACOVENCO, 1993; VIEGAS, 2001), Bohn assumes that, because /o/ is more stable than /e/ in this position, it is acquired first.

Our hypothesis is that not only is stability relevant in the emergence and acquisition of segments, but also that the order of acquisition follows a Principle of Contrast, which governs the emergence of segments, following the assumptions of Contrastive Hierarchy Theory (hereinafter CHT, DRESHER, 2009).

In order to argue in favor of this analysis, this paper is organized as follows: the first section reviews previous studies on the acquisition of vowels in BP; the second section presents the assumptions of CHT and an analysis on BP phonology within this theoretical framework. The third section provides a summary of Bohn (2015)'s work on vowel acquisition in PB based on CHT. In the fourth and fifth sections we present the methodology and results found in the study. The sixth and seventh sections present a general discussion of the results and the final considerations, respectively.

\section{Vowel Acquisition - previous studies}

Studies of the acquisition of the phonological inventory date back to the last century. Jakobson (1968[1941]) was the first to propose an order of acquisition for segments, and he proposed that the acquisition process is guided by maximum contrasts and its order is universal. With respect to vowels, the first contrast is between consonants and vowels (the consonant being the most closed one - the labial stop /p/ - vs the most open vowel - /a/). The next contrast is between the low and high vowels (/a/ vs /i/). The following contrast can occur either with respect to frontiness (front /i/ vs. /u/) or height (high vs. mid - /i/ vs. /e/). Many studies, however, have drawn attention to the amount of variability found in children's data, calling into question the universal analyzes (eg, 
VIHMAN et al., 1986; MACKEN, 1979; PYE et al., 1987, among others), but still today many studies seek to find the Jakobsonian proposed order.

Rangel (2002) was the first to analyze the acquisition of vowels in BP. Based on Feature Geometry (CLEMENTS; HUME, 1995), and making use of two corpora, a cross-sectional study of 72 children and a longitudinal study of three children (from 1:0 to $1 ; 11$ years old), Rangel proposes that the child begins the acquisition of PB vowels with all places of articulation specified while acquiring the aperture nodes gradually, arguing in favor of the following order of acquisition: $1^{\text {st }}$ stage $(/ a>i>u /)$, $2^{\text {nd }}$ stage $(/ \mathrm{e}>\mathrm{O} /)$, and $3^{\text {rd }}$ stage $(/ \mathrm{o}>\varepsilon /)$. This proposal describes exactly the acquisition path suggested by Jakobson, but it is not enough to explain why vowels which are distinguished only by place of articulation are not acquired simultaneously. Also, in Rangel's analysis, the coronal vowel precedes the acquisition of the labial in the first and second stages, but in the third stage we find the labial vowel being acquired before the coronal vowel. In order to explain these differences, Rangel proposes that vowels are acquired in sub-stages.

Also, although Rangel proposes a single order of acquisition for the cross-sectional and longitudinal studies, the results found for each of these studies show differences in how contrasts are established, as shown in Table 1 below.

Table 1 - Order of vowel acquisition.

\begin{tabular}{|l|l|}
\hline Cross-sectional: & $\mathrm{a}>\mathrm{i}, \mathrm{u}>\mathrm{e}, \mathrm{o}>\mathrm{\rho}>\varepsilon$ \\
\hline Child Gabi: & $\mathrm{a}, \mathrm{i}>\mathrm{u}>\mathrm{e}, \mathrm{o}>\mathrm{\rho}>\varepsilon$ \\
\hline Child Ana: $^{1}$ & $\mathrm{a}, \mathrm{i}, \mathrm{u}>\mathrm{o}>\mathrm{e}, \varepsilon, \mathrm{c}$ \\
\hline
\end{tabular}

Source: Rangel (2002).

With regard to the unstressed position, although Rangel takes into account all the vowels produced in the word and classifies them according to stress, she only does so to verify whether the syllable stress would be a facilitator favoring the correct production of vowels. Rangel observes, however, that stress is not always a strong factor for the correct production of vowels: in the cross-sectional study, for example, the correct production of the vowel /i/ was in the pos-tonic syllable, while for /e/ and /o/ the most favorable position was the stressed syllable. In the longitudinal study, the pre-tonic syllable was the most favorable for both /e/ and /o/. In her study, stress was also a factor shown as relevant for the neutralization of $/ \mathrm{e} /$ and $/ \mathrm{o} /$ in the final pos-tonic position. Based on these results, Rangel assumes a pos-tonic vowel system consisting of three vowels up to the age of 1;5 and a pos-tonic vowel system consisting of five vowels /a, e, i, o, u/ from the age of $1 ; 6$ on.

This is based on the Phonological inventory shown for this child on Table 6 (RANGEL, 2002, p.111), but we hightligh that, in Table 7 (p.122), the order presented is different: $/ \mathrm{a}, \mathrm{e}, \mathrm{i}, \mathrm{o}, \mathrm{u} />/ \varepsilon, \mathrm{o}$. 
Another proposal for the acquisition of BP vowels comes from Miranda and Matzenauer (2009)'s analysis based on Lee (2008)'s model for the BP vowels. According to Lee, BP vowels are specified with three features: [high], [low] and [ATR]. Miranda and Matzenauer base their analysis on Rangel (2002)'s results but disconsider the difference in the period of acquisition between the mid-low vowels / $\varepsilon /$ and $/ \mathrm{\rho} /$ (only one month. Consequently, Miranda and Matzenauer argue in favor of three stages in the acquisition of BP vowels (/a, i, $\mathrm{u} />/ \mathrm{e}, \mathrm{o} />/ \varepsilon, \mathrm{o} /$ ), eliminating the sub-stages proposed by Rangel. It must be highlighted, however, that despite distinguishing three vowel sub-systems in PB by different height levels (stressed position with four levels, pretonic position with three and pos-tonic position with two), Miranda and Matzenauer do not look into the acquisition of these sub-systems separately, similarly to Rangel.

One other study is Bonilha (2004), which analyzes data from one child acquiring PB. According to her, the child acquires BP vowels in three stages: $1^{\text {st }}(/ \mathrm{a}, \mathrm{e}, \mathrm{i}, \mathrm{o}, \mathrm{u} /$ ), $2^{\text {nd }}(/ \varepsilon /)$, and $3^{\text {rd }}(/ \supset /)$, all before the age of $1 ; 9$. However, Bonilha (2004) herself points out that her analysis is based on a small number of data. Working within the Optimality Framework, she argues that the vowel inventory of the first stage indicates that there has been a demotion of markedness constraints, which results in the hierarchy as in (1):

(1) $\mathrm{H} 1=$ Fidelity $>\{$ * [dorsal], * [labial], * [coronal], * [+ open 1], * [+open2], * [+open3], *[-open1], *[-open2], *[-open3], * [+ sonorant], * [+ aproximant $]$ $*$ [+ vocoid $], *$ [+ voiced $], *$ [+ continuant $]$,

However, this hierarchy of constraints would also allow the acquisition of the mid-low vowels at this moment. Therefore, the author suggests that a conjuction of constraints drives the process as in (2):

(2) $\mathrm{H} 1=\{*$ [ +open3] \& $*$ [labial $]]$ (seg), [[* +open 3] \& * [coronal $]]$ (seg) $\}$ $>>$ Fidelity $>\{\{$ [dorsal], * [labial], *[coronal], *[+open1], *[+open2], $*$ [+open3], *[-open1], *[-open2], *[-open3], *[+sonorant], *[approximate], $*$ [+ vocoid $], *[+$ voiced $], *[+$ continuant $]\}$

Once demoted below the faithfullness constraints, the constraint conjunction would be deconstructed. The difference between the stages of acquisition of $/ \varepsilon /$ and $/ \mathrm{s} /$ would result from the different moments of the demotion of [[* [+ open3] \& * [coronal $]$ (seg) and $[*[+$ open 3$] \& *$ [labial $]]$ (seg). With the demotion of $[[*[+$ open3 $] \& *$ [labial $]]$ (sec), the child acquires $/ \mathrm{s} /$, but does not yet acquire $/ \varepsilon /$. What draws our attention is the different order of acquisition of the vowels in relation to the other studies (as for Bonilha five vowels would be acquired at the same time). However, as Bonilha only analyzes data from one child, it is not possible to know what type of analysis would be done if variability were to be found.

Subsequent studies specifically focused on the acquisition of pre-tonic vowels. Matzenauer (2009), based on Lee (2008), focuses on the acquisition of these vowels to verify not only the order of emergence of the segments in this position but also the child's sensitivity to phonological processes affecting pre-tonic vowels. Matzenauer's 
analysis is cross-sectional and is based on data from 72 children aged 1;2 to 2;1, divided into 12 age groups. Based on Rangel (2002)'s and Miranda and Matzenauer (2007)'s proposals, Matzenauer claims that, in the pre-tonic position, acquisition takes place in two stages only, since the mid-low vowels $/ \varepsilon /$ and $/ \supset /$, acquired in the third stage, are not licensed in this position. In the first stage the low vowel /a/, and the high vowels /i, $\mathrm{u} /$ are acquired, resulting from a maximum contrast of height; in the second stage, the mid-high vowels /e, o/. In spite of arguing in favor of stages, Matzenauer points out that mid-high vowels emerge almost simultaneously to high vowels in the pre-tonic position and finds that their first productions occur mainly in reduplications. According to Matzenauer, although the emergence of pre-tonic vowels occurs early, their acquisition is not immediate. These vowels are subject to many phonological processes, in particular the mid-high vowels, which tend to be realized as a high vowel.

With a view to understanding the lexical representation of pre-tonic vowels, especially the mid-high ones, Miranda (2013) analyzes data from one child acquiring BP. Her analysis investigates two hypotheses: (i) the segments are stored in the lexical representations as discrete and autonomous entities, regardless of the syllabic position they occupy; (ii) there is a difference in how vowels are acquired based on the syllabic position they occupy. Miranda observes that between ages 1;8 and 2;4, pre-tonic mid vowels are either produced as high or mid. According to her, the fact that there is no such variation in the stressed position in this child's data reinforces the fact that the pretonic position is a place of instability in the acquisition. This confirms the hypothesis that the child is sensitive to the syllabic position a vowel occupies. For Miranda, there seems to be no strong opposition between mid and high in the pre-tonic position, which provides space for experimentation for the child. Thus, the segments are acquired based on how they operate in the system, not as simple units of a set.

Vogeley (2011) also assumes that the acquisition reflects the variation found in the adult language. She analyzes pre-tonic data from the Recife dialect, which presents mid-low vowels in this position, and hypothesizes that the emergence of vowels in the pre-tonic position in this dialect is different from other dialects (VOGELEY; HORA, 2008). ${ }^{2}$ Based on a qualitative analysis, the order proposed by Vogeley for the dialect of Recife is: $1^{\text {st }}$ stage $(/ \mathrm{a}, \mathrm{i}, \mathrm{u} /), 2^{\text {nd }}$ stage $(/ \varepsilon, \mathrm{e} /), 3^{\text {rd }}$ stage $(/ \mathrm{o}, \mathrm{o} /)$. With regard to the the acquisition of pre-tonic vowels, her results show the acquisition of the mid-low vowels before the mid-high ones, with the front vowel being acquired before the back vowel, with the following order: $1^{\text {st }}$ stage $(/ \mathrm{a}, \mathrm{i}, \mathrm{u} /), 2^{\text {nd }}$ stage $(/ \varepsilon /), 3^{\text {rd }}$ stage $(/ \mathrm{o} /)$. Vogeley proposes an underlying representation for the vowel system of the Recife dialect which licenses the mid-low vowels in the pre-tonic position, but points out that this does not mean that there should be a contrast between $/ \varepsilon, \mathrm{o} /$ and /e, o/ in this position, as the mid-high vowels are still produced in this dialect by vowel harmony when followed by another mid-high vowel, as is the case of [sor.'ve.te] 'sorvete'/ 'ice cream' and

In this analysis, conducted with a small number of data (the four children had between 9 and 49 tokens each) the author took into account all vowels produced, i.e. stressed and unstressed. 
[se.'bo.la] 'cebola'/ 'onion', for example. In this sense, Vogeley (2011) argues in favor of the existence of an underlying representation of pre-tonic vowels in PB where these vowels are underspecified in terms of height and later specified according to the dialect. According to Feature Geometry Theory (CLEMENTS; HUME, 1995), this means that $\left[\right.$ open $_{3}$ ] is phonologically deactivated in the underlying representation and is only specified when inserted in a dialect - for the Southern dialect, known as gaucho, there is activation of [-open $n_{3}$, and for the Recifense dialect, $\left[{ }^{\circ}\right.$ open $\left._{3}\right]$ in the pre-tonic position.

None of the studies described so far take into account the variability oftentimes found in children's data. Bohn (2015) attempts to account for this variability. As the author develops her analysis by assuming CHT, we show her results after presenting the main characteristics of this theory in the following section.

\section{Contrastive Feature Hierarchy and Brazilian Portuguese}

As we saw in the previous section, phonological proposals that assume universal features or hierarchies cannot account for the variability oftentimes found in children's data or how systems with the same phonological inventories may be subject to different phonological processes. CHT proposes a formal, uniform model which accounts for variability both among systems and among individuals speaking the same language (cf. DRESHER, 2009).

Dresher (2015, p.165, emphasis added) proposes that

[...] the phonological component of grammar computes features, but these features are not innate. Rather, they are created by the learner as part of the acquisition of phonology. Further, Universal Grammar (UG) requires that these features be organized into contrastive feature hierarchies that reflect phonological activity and the contrasts in the lexical inventory.

That is, for Dresher, what is universal is the structure and the hierarchical organization of features, and not features themselves. It is the concept of a hierarchy of features that is inherent in the phonological grammar, not its substance. And it is through an innate capacity to perceive acoustic correlates that features are identified and hierarchized.

According to CHT, the phonological representations of segments are based on phonological contrasts and on the phonological processes affecting them. In fact, the idea of contrast has been fundamental in the linguistic analyzes of phonological grammars in order to determine the phonemes of a phonological inventory and its internal organization. However, Dresher stresses that the initial proposals of contrastive hierarchies (such as that of CHERRY; HALLE; JAKOBSON, 1952; HALLE, 1971) did not establish clear criteria for the determination and arrangement of contrastive features in a branched and hierarchical structure. CHT is intended to rescue the notion 
of contrast and hierarchy in a model of phonological grammar, accounting for the lack of consensus in the previous proposals. For Dresher, if contrastive hierarchies vary from language to language, there needs to be a strategy to determine which features are contrastive in each system. Dresher assumes that the phonological grammar computes only features that are active in the system and dispenses with redundant ones, adopting the Contrastive Hypothesis formulated by Hall (2007, p.87), according to which, "The phonological component of a language L operates only on those features which are necessary to distinguish the phonemes of L from one another."

As for the organization of features, Dresher (2009) proposes that it should be done following the Successive Division Algorithm, hereinafter SDA, which determines that all segments of the inventory must receive a representation that distinguishes each from all the others. The algorithm consists of the following steps:

(3) a) Begin with no specification: assume all sounds are allophones of a single undifferentiated phoneme

b) If the set is found to consist of more than one contrasting member, select a feature and divide the set into as many subsets as the feature allows for

c) Repeat step (b) in each subset: keep dividing up the inventory into sets, applying successive features in turn, until every set has only one member. (DRESHER, 2009, p.16)

As only the concept of a hierarchical contrastive structure and the division algorithm are innate, and there is no pre-established order for the organization of features, nothing prevents the same set of phonemes from having different organizations. For an inventory such as /a, i, u/, for example, we can have [high] as the first contrast, dividing the set into two groups: /i, u/ being specified with [+ high] and /a/ with [-high]; second, we divide the [+high] vowels - which are still uncontrasted - into [+ rounded] $(/ \mathrm{u} /)$ and [-rounded] (/i/). In this representation, the [high] feature contrasts all segments, while [rounded] is relevant only for /i/ and / $\mathrm{u} /$ - cf. (4a). This same inventory, in another language, could have a different hierarchical order of features, starting with [rounded]. In this second hierarchy, all segments of the inventory receive the [rounded] contrast and only /a/ and /i/ will contrast in terms of [high] - cf. (4b).

Figure 4 - a) Hierarchy starting with [high], b) Hierarchy starting with [round]
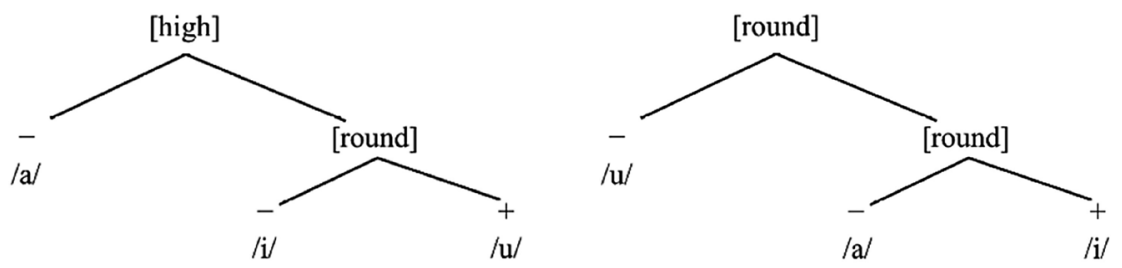

Source: Adapted from Mackenzie (2009, p.13). 
These different configurations capture facts such as why there are languages in which processes affect /i, u/ but not/a/, while in others, processes affect /i, a/ but not/u/.

We would like to point out, however, that Dresher does not explain what would trigger the SDA to be applied. That is, Dresher's proposal is based on the fact that the features must be contrastive; the SDA is an algorithm that divides an allophonic inventory based on contrastive features; but there is no mention of a principle that governs this application, as noted in Dresher (2015, p.172, emphasis added):

At some point the learner discovers a contrast between a [low] vowel /A/ and a non-low vowel/I/ (the symbols are for convenience only). [...] Consider, for example, the first contrast in the vowel system, that between low and non-low vowels. How does the learner know to include [ə] with the low vowels rather than with the non-low vowels? Part of the answer must be that [ə] alternates with [a] as its ATR counterpart. This suggests that even at the first step in the idealized acquisition sequence there must be a certain amount of look-ahead that makes use of information about contrasts later on in the sequence.

In addition to the concept of contrast, another assumption of CHT is that the hierarchical order must also be determined by the way the segments operate in the phonological systems of the language, unlike the hierarchical universal ordering based on articulatory motivations adopted by Feature Geometry (CLEMENTS; HUME, 1995), for example. This means that the variability between the different contrastive hierarchies reflects how each system is affected by phonological phenomena. The choice between the two possible hierarchies for the same inventory /a, i, u/ shown above will therefore depend on the relevance of each feature in the phonological processes of the language. In the second proposed hierarchy, in which $/ \mathrm{u} /$ is specified only for roundness, we could say that in this system, $/ \mathrm{u} /$ is affected by processes in which only roundness is relevant; that is, despite being a high vowel, the height feature is not active in the processes that affect this vowel, and, therefore, it is not part of its phonological representation. ${ }^{3}$

Lee (2008) proposes a contrastive hierarchy for vowels in BP, according to CHT, cf. (5):

Analyses of this type can be found in Zhang (1996), Dresher (2009) and Mackenzie (2009). 
Figure 5 - Contrastive Hierarchy of PB vowels proposed by Lee (2008)

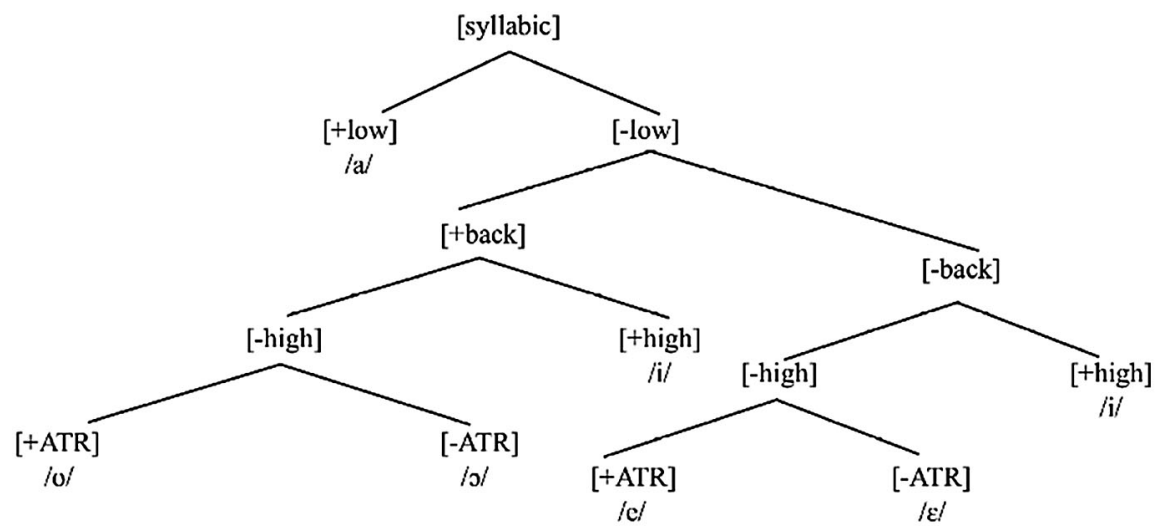

Source: Lee (2008, p.7)

Bohn (2015) points out that Lee's proposal accounts for the phonological processes affecting BP vowels described by Bisol (1996), including vowel elision, which, according to Bisol, affects only /a/ in the Southern dialects; Lee's hierarchy, however, does not account for the elision process as it occurs in the Paulista dialect, where it affects all unstressed back vowels /a, u, o/ (cf. NOGUEIRA, 2007 and SANTOS, 2007). Bohn's proposed hierarchy captures the process as it occurs in the Paulista dialect:(6)):

Figure 6 - Contrastive Hierarchy of PB vowels proposed by Bohn (2015)

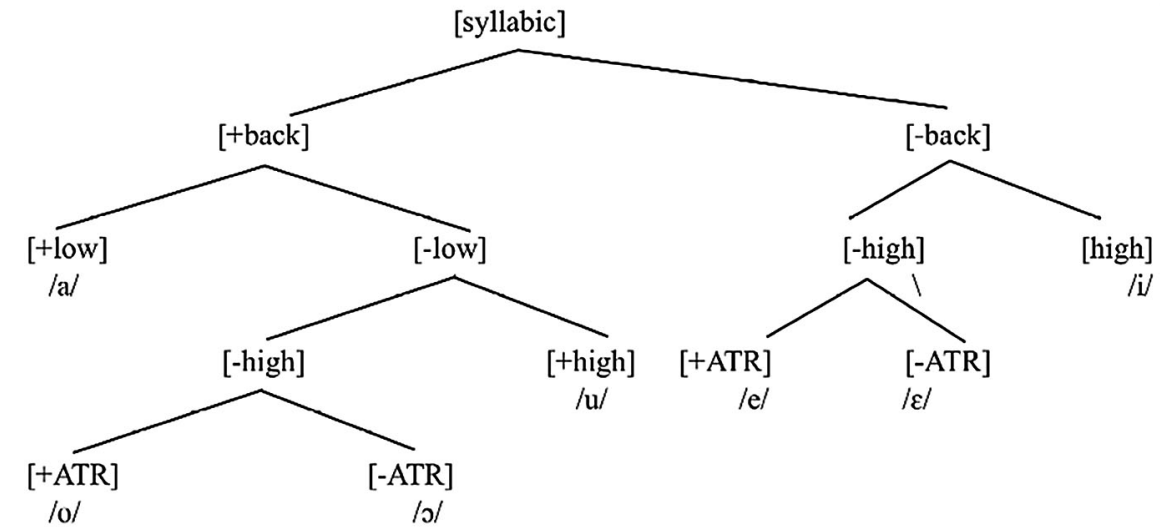

Source: Bohn (2015, p.147) 
We understand that the existence of two hierarchies for the same language is not a problem for CHT; it is also what explains variability within a language: one phonological inventory with different organizations. And it is through how phonological processes function in the language that we can realize the different organization of inventories.

The implementation of CHT in acquisition raises an important question for both theory and data: is it possible for children to build different hierarchies?

\section{CHT and phonological acquisition}

In her study, Bohn (2015) shows that three children exposed to the Paulista dialect of BP follow different paths when acquiring the vowel system of the language. By analysing longitudinal data, Bohn reconstructed the contrastive hierarchies taking into account the order in which vowels became frequent in the speech of each child (following the methodology proposed by Ingram, 1989) and the substitutions found in the data. If, for instance, in an initial stage only one vowel is frequent in a child's speech, the contrast is between vowels vs. non-vowels, represented by Bohn with the [syllabic] feature. If another vowel becomes frequent, a second contrast is specified (which characterizes another stage ${ }^{4}$ ), and so on, until all vowels have enough contrasts that distinguish them from all the others. The existence of two or more vowels under the same contrast can be evidenced in the substitutions found in children's productions. For example, the productions ['aze] for /'xoza/ 'rosa'/'pink' (1;9), ['podo] for/sa'patu/ 'sapato'/ 'shoe' $(1 ; 8)$, and [pute] for /'porta/ 'porta'/'door' $(2 ; 0)$ for child L. indicate that $/ \mathrm{a} /, / \mathrm{o} /, / \mathrm{o} /$ and $/ \mathrm{u} /$ share a contrastive feature and, as the hierarchy is being constructed, these vowels should contrast with each other. The advantage of this model is to explain the variability found in several longitudinal acquisition studies and also attested to in Bohn's data: while one child begins the hierarchy with a contrast in height (Child A.), the others (Children Am. and L.) begin with a contrast in place and follow the same order in the acquisition of contrastive features despite presenting a different order of vowel acquisition. As seen in (7) below, all children begin by contrasting /a/ with all the other vowels. However, child A. almost concomitantly acquires /o/, whereas children Am. and L. acquire /e/ and /i/, respectively:

(7) a. Child A.: / a,o / / i, e, u $/>/ \mathrm{o}, \varepsilon /$

(see representation in (5))

b. Child Am .:/ a $/>/ \mathrm{e} />/ \mathrm{o} />/ \mathrm{i} />/ \mathrm{o}, \mathrm{u}, \varepsilon /$ (see representation in (6))

c. Child $\mathrm{L} .: / \mathrm{a} />/ \mathrm{i} />/ \mathrm{e}, \mathrm{o} />/ \mathrm{o}, \varepsilon />\mathrm{u} \quad$ (see representation in (6))

As mentioned, CHT uses the phonological processes affecting segments as clues for the organization of the features in the hierarchy. Thus, the child does not build classes (or nodes, in terms of Feature Geometry) that group vowels that are not subject to the

New stages can be due to the acquisition of vowels or to the reorganization of features in the hierarchy - cf. Bohn (2015). 
same phonological process. For example, a child acquiring BP will not use [a, e, i] allophonically as there are no phonological processes affecting these three vowels in $\mathrm{PB}$.

In sum, in discussing the acquisition of the vowel system in PB from the CHT perspective, Bohn can deal with the variability found among learners, which is not possible within other theoretical frameworks.

\section{Methodology}

The corpora of this study consist of data from 3 children (A., Am., L.) acquiring the Paulista dialect of BP (data from Santos, 2005). The children were recorded in their natural environment every week for 30 minutes. The amount of data collected in the stressed and pre-tonic positions for each child and the period of data collection are shown in Table 2.

Table 1 - Number of data analysed per child distributed according to stress position.

\begin{tabular}{lcccc}
\hline Child: & Age & Stressed & Pre-tonic & Total \\
\hline A. & $1 ; 0-2 ; 11$ & 3.761 & 3.009 & 6.770 \\
\hline Am. & $1 ; 02-3 ; 05$ & 1.540 & 890 & 2.430 \\
\hline L. & $1 ; 04-2 ; 11$ & 2.633 & 1.511 & 4.144 \\
\hline
\end{tabular}

Source: Adapted from Bohn (2015, p. 108).

As we have seen, CHT assumes that children can have the same phonological inventory, but build different structures to contrast phonemes. One methodological consequence of this assumption is that cross-sectional data should not be analyzed within this framework, as children in the same age range can have the same phonological inventories but may organize them into different structures. Only by looking into longitudinal data and observing the emergence of phonemes and substitutions is it possible to infer what hierarchies children are building. For this reason, the data of these three children are analyzed separately in this study.

The word productions to be considered in the analysis is also a decision that has important consequences for the results. For example, it is not possible to observe substitutions in words created by the children, as there is no target word for comparison. Therefore, only words that are part of the lexicon of the language were considered in the study.

Productions were considered correct taking into account the adult language. However, cases that show a variation in the adult form were not considered substitutions (e.g. in [ka.'de] [ke.'de] for /ka'de/ 'cadê'/'where', in which the production of [e] was not considered as a substitution for /a/ as both forms are also attested in adult speech). The data were phonetically transcribed and, in cases of doubt, the F1 and F2 
frequencies of the vowel were used as parameters for the final transcription. ${ }^{5}$ In addition, special attention was paid to productions that could result from phonological processes. The literature on the acquisition of phonological rules in the adult language is still scarce in BP (but cf. SILVA, 2008; SANTOS, 2007), but less sparse on phonological processes which are typical of children's speech. However, these rules and processes may conceal the acquisition of phonemes. Our decision, then, was not to work with productions that could be the result of a phonological process of the adult language. For example, the production of [si'gu.la] for /se'gura/ 'segura'/'to hold-imperative' (Am. 2;4) may be either an evidence of /i, e/ being acquired (in this stage, as we will see in Table 4, the vowel /e/ is still not used very often by this child), or the result of a process of vowel harmony. Other examples are cases of syllabic reduplication, such as [te.'ta.ta.ta] for /ga'veta/ 'gaveta' / 'drawer' (Am. 2;10), a process which is typical of language acquisition. These types of data could bias the results, so they were not considered in the analysis.

Finally, an important methodological decision is the use of types or tokens. It is not uncommon in the literature of phonological acquisition to see that children succeed in producing a segment correctly in a specific word, whereas in other words the same segment is constantly being replaced. This may be due to being a segment that appears in the child's name, the name of a close person or even a favorite toy, that is, a word which is produced frequently. If an analysis is conducted by tokens and one word occurs constantly, the results could wrongly suggest the acquisition of a phoneme. For this reason, a number of current analyzes consider that the child should present a minimum percentage of correct productions in different types. In this study, the data were extracted and organized according to the methodology proposed by Ingram (1981, 1989). According to this methodology, the analysis is guided by phonetic types. In the case of variability in production, Ingram's methodology sets up criteria for deciding which phonetic type should be used in the analysis, described in (8) below (1989, p. 204):

(8) a) If a phonetic type occurs in a majority of the phonetic tokens, select it.

b) If there are three or more phonetic types, select the one that shares the most segments with the others.

c) If there are two phonetic types, select the one that is not pronounced correctly.

d) If none of the above work, select the first phonetic type listed.

\footnotetext{
Because the vocal tract of the child is still developing, and variation in formants may be found, Bohn uses the child's own productions as a formant parameter to classify the vowel productions, and not the values found in the literature. Hence, the frequencies of two productions of each stressed and pre-tonic oral vowel clearly produced by each child were measured, in each session, in order to obtain the means of the formants of each vowel for each child at that session. To illustrate this procedure, we have here the production [pega] for /pega/ pega 'catch-imperative' of L. (verb in the imperative, second person singular) at age 1;9. The mean of F1 and F2 of vowel [e] in this production presented the following values: $831.31 \mathrm{~Hz}$ and $1701.12 \mathrm{~Hz}$, respectively. The approximation of these values with the average obtained for vowel /e/ in the stressed position at that age for this child $(\mathrm{F} 1=892.09 \mathrm{~Hz}$ and F2 $=1745.30 \mathrm{~Hz})$ allowed Bohn to classify the production as a mid-high front vowel and not as a mid-low front vowel (which, for this child at this age, presented the following values: $\mathrm{F} 1=1028.86 \mathrm{~Hz}$ and $\mathrm{F} 2=2218.56 \mathrm{~Hz}$ ).
} 
Sounds produced by children are then classified into three frequency categories (marginal, in use, frequent), which vary according to the size of each sample. Table 3 shows the frequency criteria for vowels. When the child has a sample of 1 to 25 types, a certain sound must occur four times or more to be considered frequent in their speech; if it occurs two or three times, it will be considered in use, and if it occurs only once, it will be considered marginal. As the number of phonetic types increases in a sample, so does the number of times the sound should appear.

Table 2 - Phonetic types and frequency criteria.

\begin{tabular}{cccc}
\hline Number of phonetic types & Marginal (low) & In use (medium) & Frequent (high) \\
\hline $1-25$ & 1 & 2,3 & 4 or more \\
\hline $26-37$ & 2 & 3,4 & 5 or more \\
\hline $38-67$ & 2 & $3-5$ & 6 or more \\
\hline $68-87$ & 3 & $4-6$ & 7 or more \\
\hline $88-112$ & 3 & $4-7$ & 8 or more \\
\hline 113 or more & 4 & $5-8$ & 9 or more \\
\hline
\end{tabular}

Source: According to Fee (1991, p.351).

This first step generates the phonetic inventory of the child. In the second step of this methodology, the substitutions are computed, providing evidence of which phonological contrast has already been acquired and which segments are still being used allophonically.

With the information in steps 1 and 2, the children's phonological inventory is organized. According to this method, a sound will be considered acquired in the child's phonological system when (i) it is classified as frequent; or (ii) it is classified as in use but also appears as a substitute for another sound. Ingram points out that there must be consistency in the classification of a sound as frequent in the samples. That is, the classification as frequent must be maintained in all subsequent samples, which indicates that this methodology must only be applied to longitudinal data.

\section{Results}

The results by types brought in this section are reported in Bohn (2015), but will be arranged differently in order to facilitate our discussion.

Table 4 below shows the order of acquisition of vowels, in stressed and pre-tonic position, for each child; Tables 5 and 6 present the substitutions produced by each child for vowels in stressed position; and Tables 7 and 8 , the substitutions produced by each child for the vowels in the pre-tonic position. 
Table 3 - Order of acquisition of stressed and pre-tonic vowels for each child.

\begin{tabular}{|c|c|c|c|c|c|c|c|}
\hline \multirow{2}{*}{\multicolumn{2}{|c|}{ Stressed }} & \multicolumn{2}{|c|}{ A. } & \multicolumn{2}{|c|}{ Am. } & \multicolumn{2}{|c|}{ L. } \\
\hline & & \multirow{2}{*}{ Pre-tonic } & \multirow{2}{*}{ Stressed } & \multirow{2}{*}{ Pre-tonic } & \multirow{2}{*}{ Stressed } & \multirow{2}{*}{ Pre-tonic } & \\
\hline \multirow{26}{*}{ Age } & $1 ; 1$ & & & & & & \\
\hline & $1 ; 2$ & & & & & & \\
\hline & $1 ; 3$ & & & & & & \\
\hline & $1 ; 4$ & & & & & $/ \mathrm{a} /$ & \\
\hline & $1 ; 5$ & & & & & & \\
\hline & $1 ; 6$ & $/ \mathrm{a}, \mathrm{o} /$ & /a/ & & & $/ \mathrm{i} /$ & $/ \mathrm{a} /$ \\
\hline & $1 ; 7$ & & $10 /$ & & & & \\
\hline & $1 ; 8$ & $/ \mathrm{i}, \mathrm{e}, \mathrm{u} /$ & /i/ & & & $/ \mathrm{e}, \mathrm{o} /$ & \\
\hline & $1 ; 9$ & & & & & & \\
\hline & $1 ; 10$ & $/ 0 /$ & & $/ \mathrm{a} /$ & & $\mid 0, \varepsilon /$ & \\
\hline & $1 ; 11$ & $|\varepsilon|$ & & /e/ & $/ \mathrm{a} /$ & $/ \mathrm{u} /$ & $/ \mathrm{o}, \mathrm{i} /$ \\
\hline & $2 ; 0$ & & le/ & & & & $/ \mathrm{u} /$ \\
\hline & $2 ; 1$ & & $/ \mathrm{u} /$ & & & & \\
\hline & $2 ; 2$ & & & & & & \\
\hline & $2 ; 3$ & & & $10 /$ & & & \\
\hline & $2 ; 4$ & & & /i/ & & & \\
\hline & $2 ; 5$ & & & & & & \\
\hline & $2 ; 6$ & & & & & & \\
\hline & $2 ; 7$ & & & & & & /e/ \\
\hline & $2 ; 8$ & & & & $10 /$ & & \\
\hline & $2 ; 9$ & & & & & & \\
\hline & $2 ; 10$ & & & & & & \\
\hline & $2 ; 11$ & & & & /i/ & & \\
\hline & $3 ; 0$ & & & $/ \mathrm{o}, \mathrm{u} /$ & & & \\
\hline & $3 ; 1$ & & & $|\varepsilon|$ & & & \\
\hline & $3 ; 2$ & & & & /e/ & & \\
\hline
\end{tabular}

Source: Adapted from Bohn (2015, p.111-137). 
Table 4 - Phoneme substitutions in stressed position for each child (1;4 to $2 ; 3)$.

\begin{tabular}{|c|c|c|c|c|c|c|c|c|c|c|c|c|c|c|c|c|}
\hline & phonemes & $1 ; 1$ & $1 ; 2$ & $1 ; 3$ & $1 ; 4$ & $1 ; 5$ & $1 ; 6$ & $1 ; 7$ & $1 ; 8$ & $1 ; 9$ & $1 ; 10$ & $1 ; 11$ & $2 ; 0$ & $2 ; 1$ & $2 ; 2$ & $2 ; 3$ \\
\hline \multirow{8}{*}{ A } & $/ \mathrm{a} /$ & & & & & & & & & & & & & & & \\
\hline & /i/ & & & & & & & & & & & & & & & \\
\hline & $/ \mathrm{u} /$ & & & & & & & & & & & & & & & \\
\hline & /e/ & & & & & & & & & & & & & & & \\
\hline & $/ \mathrm{o} /$ & & & & & & & & & & & & & & & [0](1) \\
\hline & $/ \varepsilon /$ & & & & & & & & {$[\mathrm{e}](1)$} & {$[\mathrm{e}](2)$} & {$[\mathrm{e}](4)$} & {$[\mathrm{e}](1)$} & {$[\mathrm{e}](1)$} & {$[\mathrm{e}](1)$} & {$[\mathrm{e}](4)$} & \\
\hline & $/ \mathrm{J} /$ & & & & & & & & {$[0](1)$} & {$[\mathrm{o}](3)$} & {$[0](2)$} & & {$[\mathrm{o}](2)$} & {$[0](2)$} & {$[0](6)$} & {$[0](2)$} \\
\hline & $\begin{array}{c}\text { Number of } \\
\text { types }\end{array}$ & 0 & 1 & 4 & 4 & 7 & 12 & 6 & 61 & 111 & 193 & 206 & 247 & 297 & 381 & 298 \\
\hline \multirow{8}{*}{ Am } & /a/ & & & & & & & & & & & & & & & \\
\hline & /i/ & & & & & & & & & & & & & & & \\
\hline & $/ \mathrm{u} /$ & & & & & & & & & & & & & & & \\
\hline & /e/ & & & & & & & & & & & & & & & \\
\hline & $/ 0 /$ & & & & & & & & & & & & & {$[\mathrm{u}](1)$} & & \\
\hline & $/ \varepsilon /$ & & & & & & & & & & {$[a](1)$} & & & & & \\
\hline & $/ 0 /$ & & & & & & & & & & & & & & & {$[0](1)$} \\
\hline & $\begin{array}{c}\text { Number of } \\
\text { types }\end{array}$ & - & 0 & 0 & 1 & 1 & 0 & 4 & 4 & 3 & 7 & 10 & 28 & 32 & 36 & 30 \\
\hline \multirow{8}{*}{$\mathrm{L}$} & /a/ & & & & & & & & {$[0](1)$} & & & & {$[0](1)$} & & & \\
\hline & /i/ & & & & & & & & & & & & & {$[\mathrm{e}](1)$} & & \\
\hline & $/ \mathrm{u} /$ & & & & & & & & & & & & & & & \\
\hline & /e/ & & & & & & & & & & & & & {$[i](2)$} & & \\
\hline & $/ \mathrm{o} /$ & & & & & & & & & {$[\mathrm{u}](1)$} & {$[\mathrm{u}](2)$} & {$[\mathrm{u}](2)$} & & & {$[\mathrm{u}](2)$} & \\
\hline & $/ \varepsilon /$ & & & & & & & & & \begin{tabular}{|l}
{$[\mathrm{e}](2)$} \\
{$[\mathrm{i}](1)$}
\end{tabular} & {$[\mathrm{e}](2)$} & & {$[\mathrm{e}](4)$} & {$[\mathrm{e}](3)$} & $\begin{array}{l}{[\mathrm{e}](2)} \\
{[\mathrm{i}](1)}\end{array}$ & $\begin{array}{l}{[\mathrm{e}](2)} \\
{[\mathrm{i}](1)}\end{array}$ \\
\hline & /0/ & & & & & & & {$[a](1)$} & {$[0](1)$} & {$[\mathrm{o}](1)$} & $\begin{array}{l}{[\mathrm{a}](2)} \\
{[\mathrm{o}](1)}\end{array}$ & $\begin{array}{l}{[0]} \\
\text { (1) }\end{array}$ & $\begin{array}{l}{[\mathrm{o}](2)} \\
{[\mathrm{u}](2)}\end{array}$ & $\begin{array}{l}{[\mathrm{o}](2)} \\
{[\mathrm{a}](1)}\end{array}$ & {$[\mathrm{o}](2)$} & \\
\hline & $\begin{array}{c}\text { Number of } \\
\text { types }\end{array}$ & - & - & - & 22 & 13 & 16 & 28 & 52 & 124 & 101 & 182 & 210 & 231 & 205 & 148 \\
\hline
\end{tabular}

Source: Adapted from Bohn (2015, p.111-137). 
Table 5 - Phoneme substitutions in stressed position for each child (2;4 to $3 ; 5)$.

\begin{tabular}{|c|c|c|c|c|c|c|c|c|c|c|c|c|c|c|c|}
\hline & phoneme & $2 ; 4$ & $2 ; 5$ & $2 ; 6$ & $2 ; 7$ & $2 ; 8$ & $2 ; 9$ & $2 ; 10$ & $2 ; 11$ & $3 ; 0$ & $3 ; 1$ & $3 ; 2$ & $3 ; 3$ & $3 ; 4$ & $3 ; 5$ \\
\hline \multirow{8}{*}{ A } & $/ \mathrm{a} /$ & & & & & & & & & & & & & & \\
\hline & $/ \mathrm{i} /$ & & & & & & & & & & & & & & \\
\hline & $/ \mathrm{u} /$ & & & & & & & & & & & & & & \\
\hline & /e/ & & & & & & & & & & & & & & \\
\hline & $10 /$ & & & [0](1) & {$[0](1)$} & & & [0](1) & & & & & & & \\
\hline & $/ \varepsilon /$ & [e](2) & {$[\mathrm{e}](1)$} & {$[\mathrm{e}](2)$} & {$[\mathrm{e}](1)$} & [e](1) & & {$[\mathrm{e}](2)$} & {$[\mathrm{e}](2)$} & & & & & & \\
\hline & $/ 0 /$ & & {$[0](3)$} & {$[0](8)$} & {$[0](4)$} & {$[0](1)$} & {$[0](3)$} & {$[0](9)$} & & & & & & & \\
\hline & $\begin{array}{l}\text { Number } \\
\text { of types }\end{array}$ & 296 & 312 & 268 & 311 & 230 & 43 & 382 & 91 & - & - & - & - & - & - \\
\hline \multirow{8}{*}{ Am } & /a/ & & & & & & & & & & & & & & \\
\hline & /i/ & & & & & & & & & & & & & & \\
\hline & $/ \mathrm{u} /$ & & & & & & & & & & & & & & \\
\hline & $/ \mathrm{e} /$ & & & & & & & & & & & & & & \\
\hline & $10 /$ & {$[0](1)$} & & & & & & & & & & & & & \\
\hline & $/ \varepsilon /$ & & & & {$[\mathrm{a}](1)$} & {$[a](1)$} & & \begin{tabular}{|l|}
{$[\mathrm{a}](1)$} \\
{$[\mathrm{e}](1)$} \\
\end{tabular} & {$[\mathrm{a}](1)$} & & & & & & \\
\hline & $/ 0 /$ & {$[\mathrm{o}](1)$} & {$[0](2)$} & & & & {$[u](1)$} & & & & & & & & \\
\hline & $\begin{array}{l}\text { Number } \\
\text { of types }\end{array}$ & 55 & 53 & 67 & 57 & 69 & 53 & 111 & 41 & 129 & 154 & 176 & 133 & 117 & 169 \\
\hline \multirow{8}{*}{$\mathrm{L}$} & $/ \mathrm{a} /$ & & & & & & & & & & & & & & \\
\hline & $/ \mathrm{i} /$ & & & & & & & & & & & & & & \\
\hline & $/ \mathrm{u} /$ & & & & & & & & & & & & & & \\
\hline & $/ \mathrm{e} /$ & & & & & & & & & & & & & & \\
\hline & $10 /$ & & & {$[u](1)$} & & & & & & & & & & & \\
\hline & $/ \varepsilon /$ & $\begin{array}{l}\text { [e] } \\
\text { (1) }\end{array}$ & & & & & & & & & & & & & \\
\hline & $/ 0 /$ & \begin{tabular}{|l|}
$\mathrm{o}](1)$ \\
{$[\mathrm{a}](1)$} \\
\end{tabular} & & {$[0](1)$} & & & & & & & & & & & \\
\hline & $\begin{array}{l}\text { Number } \\
\text { of types }\end{array}$ & 224 & 258 & 48 & 167 & 160 & 155 & 219 & 70 & & & & & & \\
\hline
\end{tabular}

Source: Adapted from Bohn (2015, p.111-137). 
Table 6 - Phoneme substitutions in pre-tonic position for each child $(1 ; 4$ to $2 ; 4)$.

\begin{tabular}{|c|c|c|c|c|c|c|c|c|c|c|c|c|c|c|c|c|c|}
\hline & phoneme & $1 ; 1$ & $1 ; 2$ & $1 ; 3$ & $1 ; 4$ & $1 ; 5$ & $1 ; 6$ & $1 ; 7$ & $1 ; 8$ & $1 ; 9$ & $1 ; 10$ & $1 ; 11$ & $2 ; 0$ & $2 ; 1$ & $2 ; 2$ & $2 ; 3$ & $2 ; 4$ \\
\hline \multirow{6}{*}{ A } & $/ \mathrm{a} /$ & & & & & & & & & {$[\mathrm{o}](1)$} & & & & & & & \\
\hline & /i/ & & & & & & & & & {$[\mathrm{e}](1)$} & & & & & & & \\
\hline & $/ \mathrm{u} /$ & & & & & & & & & & & & & & & & {$[0](1)$} \\
\hline & /e/ & & & & & & & & & & [i](4) & {$[i](4)$} & [i] (5) & {$[i](2)$} & [i](3) & $\begin{array}{l}{[\mathrm{i}](2)} \\
{[\varepsilon](2)}\end{array}$ & $\begin{array}{l}{[\mathrm{i}](3)} \\
{[\varepsilon](2)}\end{array}$ \\
\hline & $/ 0 /$ & & & & & & & & & & {$[\mathrm{u}](5)$} & {$[\mathrm{u}](4)$} & & {$[\mathrm{u}](1)$} & {$[\mathrm{u}](2)$} & {$[\mathrm{u}](3)$} & {$[\mathrm{u}](2)$} \\
\hline & $\begin{array}{l}\text { Number } \\
\text { of types }\end{array}$ & 0 & 2 & 4 & 1 & 6 & 11 & 5 & 28 & 77 & 145 & 117 & 165 & 386 & 272 & 201 & 298 \\
\hline \multirow{6}{*}{$\mathrm{Am}$} & $/ \mathrm{a} /$ & & & & & & & & & & & & & & & & \\
\hline & /i/ & & & & & & & & & & & & & & & & \\
\hline & $/ \mathrm{u} /$ & & & & & & & & & & & & & & & & \\
\hline & /e/ & & & & & & & & & & & & & & & & \\
\hline & $/ 0 /$ & & & & & & & & & & & {$[\mathrm{u}](1)$} & & {$[\mathrm{u}](1)$} & & & \\
\hline & $\begin{array}{l}\text { Number } \\
\text { of types }\end{array}$ & 0 & 0 & 0 & 1 & 5 & 0 & 5 & 4 & 2 & 6 & 12 & 15 & 21 & 16 & 11 & 25 \\
\hline \multirow{6}{*}{$\mathrm{L}$} & $/ \mathrm{a} /$ & & & & & & & & & & & {$[\mathrm{e}](1)$} & & & & & \\
\hline & /i/ & & & & & & & & & & & {$[\mathrm{e}](1)$} & {$[\mathrm{u}](1)$} & & & & \\
\hline & $/ \mathrm{u} /$ & & & & & & & & & {$[0, \mathrm{i}]$} & & [i] & {$[\mathrm{e}, \mathrm{i}]$} & & & & \\
\hline & /e/ & & & & & & & & & [i](1) & & {$[i](6)$} & $\begin{array}{l}{[\mathrm{i}](8)} \\
{[\mathrm{a}](1)}\end{array}$ & {$[\mathrm{i}](10)$} & {$[\mathrm{i}](8)$} & {$[\mathrm{i}](6)$} & {$[\mathrm{i}](11)$} \\
\hline & $/ 0 /$ & & & & & & & & & & {$[\mathrm{u}](1)$} & & & {$[\mathrm{u}](3)$} & {$[\mathrm{u}](6)$} & {$[\mathrm{u}](7)$} & {$[\mathrm{u}](6)$} \\
\hline & $\begin{array}{l}\text { Number } \\
\text { of types }\end{array}$ & - & - & - & 11 & 3 & 22 & 20 & 32 & 45 & 56 & 90 & 109 & 102 & 97 & 102 & 138 \\
\hline
\end{tabular}

Source: Adapted from Bohn (2015, p.111-137). 
Table 7 - Phoneme substitutions in pre-tonic position for each child $(2 ; 5$ to $3 ; 5)$.

\begin{tabular}{|c|c|c|c|c|c|c|c|c|c|c|c|c|c|c|}
\hline & phoneme & $2 ; 5$ & $2 ; 6$ & $2 ; 7$ & $2 ; 8$ & $2 ; 9$ & $2 ; 10$ & $2 ; 11$ & $3 ; 0$ & $3 ; 1$ & $3 ; 2$ & $3 ; 3$ & $3 ; 4$ & $3 ; 5$ \\
\hline \multirow{6}{*}{ A } & $/ \mathrm{a} /$ & & & & & & & & & & & & & \\
\hline & /i/ & & & & & & & & & & & & & \\
\hline & $/ \mathrm{u} /$ & & & & & & & & & & & & & \\
\hline & /e/ & $\begin{array}{l}{[\mathrm{i}](4)} \\
{[\varepsilon](1)}\end{array}$ & & {$[\mathrm{i}](1)$} & & & & & & & & & & \\
\hline & /o/ & {$[\mathrm{u}](1)$} & & & {$[\mathrm{u}](1)$} & & & & & & & & & \\
\hline & $\begin{array}{l}\text { Number } \\
\text { of types }\end{array}$ & 225 & 214 & 229 & 169 & 40 & 338 & 76 & - & - & - & - & - & - \\
\hline \multirow{6}{*}{$\mathrm{Am}$} & $/ \mathrm{a} /$ & & & $\begin{array}{l}{[\mathrm{u}](1)} \\
{[\mathrm{e}](1)}\end{array}$ & & & & & & & & & & \\
\hline & /i/ & & & & & & & & & & & & & \\
\hline & $/ \mathrm{u} /$ & & & & & & & & & & & & & \\
\hline & /e/ & & & & & & {$[\mathrm{u}](1)$} & & & & [i](1) & & & \\
\hline & /o/ & & & & {$[\mathrm{u}](1)$} & & & & & & & & & \\
\hline & $\begin{array}{l}\text { Number } \\
\text { of types }\end{array}$ & 19 & 34 & 19 & 27 & 28 & 77 & 14 & 67 & 85 & 109 & 81 & 87 & 120 \\
\hline \multirow{6}{*}{$\mathrm{L}$} & $/ \mathrm{a} /$ & & & & & & & & & & & & & \\
\hline & /i/ & & & & & & & & & & & & & \\
\hline & $/ \mathrm{u} /$ & & & & & & & & & & & & & \\
\hline & /e/ & [i](20) & [i](6) & [i] (22) & [i](3) & [i](1) & [i](11) & [i](2) & - & - & - & - & - & - \\
\hline & /o/ & {$[u](12)$} & {$[u](1)$} & {$[u](15)$} & {$[u](9)$} & {$[u](7)$} & {$[\mathrm{u}](2)$} & {$[u](3)$} & - & - & - & - & - & - \\
\hline & $\begin{array}{l}\text { Number } \\
\text { of types }\end{array}$ & 202 & 51 & 166 & 81 & 49 & 94 & 41 & - & - & - & - & - & - \\
\hline
\end{tabular}

Source: Adapted from Bohn (2015, p.111-137).

Tables 5 to 8 also show the amount of data per type. For example, at 2;5, A. produced 225 different words (cf. Table 8). Of these 225 words, 5 words showed substitutions: /o/ was produced as $[\mathrm{u}]$ in one word, and /e/ was produced as [i] in four other words. As can be seen, children can show substitutions for target phonemes even after a phoneme has been acquired, but the number of substitutions decreases over time, at the same time as the number of different lexical items being produced increases. ${ }^{6}$

Tables 7 and 8 show that children produce pre-tonic syllables in a very early period: A. has some productions as early as $1 ; 2$, and begins a more productive stage at 1;9. L.

6 An item that may have been frequently substituted in a session may fail to be so at a later time. For example, child A. produces [ko.'ku.sa] for /ba'gũ.sa/ 'bagunça'/ 'mess' at 1;9 (as shown by the substitution of [o] for /a/ in Table 5). Observe, however, that this was the only time such substitution occurred. 
already produces pre-tonic syllables at 1;4 (when data started being collected) and they become more productive at 1;11. In the case of Am., some productions start at 1;5, but note that Am.'s samples are always much smaller than the other two children's, only increasing significantly after age 3;0.

As can be seen in Table 4, A. acquires pre-tonic vowels in the same order as the stressed vowels (stressed: $a, o>i, e, u>0>\varepsilon$; pre-tonic: $a>0>i>e>u$ ), with the only difference being time of acquisition, with pre-tonic vowels being acquired after the stressed vowels, except for /a/ and /i/, which are acquired simultaneously in the stressed and pre-tonic positions. In (9) we show examples of substitutions in pre-tonic position by child A.

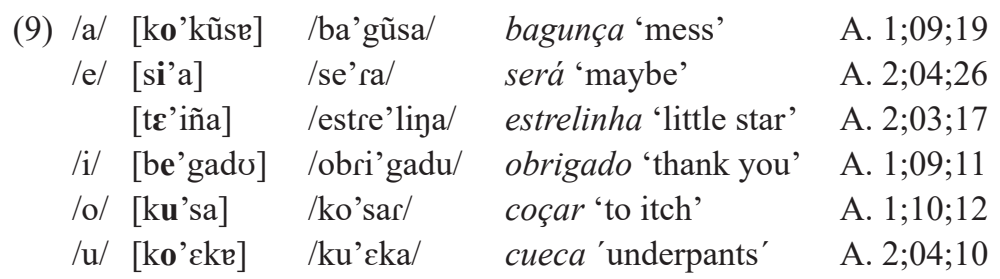

The instances of /a, i, u/ substitutions are very systematic: one lexical item each. On the other hand, /e, o/ show more substitutions than correct productions. All such cases involve their counterparts with the same place of articulation ([u] for $/ \mathrm{o} /$ and $[\mathrm{i}]$ for /e/). Correct productions for 'fechou'/fe' Jow/ and 'pesado'/pe'zadu/ occur before /e/ is acquired, but A. also produces a number of words in which /e/ is substituted by a high vowel (e.g. /3o'gar/ $\rightarrow$ [3u'ga] 'jogar'/ 'play', /to'mar/ $\rightarrow$ [tu'ma] 'tomar' / 'take', /se'ra/ $\rightarrow$ [si'a] 'será'/ 'maybe', /pe'gar/ $\rightarrow$ [pi'ga] 'pegar'/ 'pick up'). According to Bohn (2015), this alternation may be due to the fact that the child is already trying to work with the processes that affect the pre-tonic position, especially vowel harmony (as in [mi.'ni.no] for /me'nino/ 'menino'/'boy') and free context neutralization (as in [tu.'ma. tfI ] for /to'mate/ 'tomate'/'tomato'). According to these two processes, /e, i/ are produced as [i] and /o, u/ as [u]. Note that it is exactly the type of substitution that child A. does: the high vowel replaces the mid-high vowel. Bohn's analysis is corroborated by other substitutions found in the data: [ko'cke] for /ku'cka/ 'cueca'/'underpants', [be'gado] for /o.bri'gado/ 'obrigado'/‘thank you', [ko'kũse] for /ba'gũsa/ 'bagunça'/ 'mess', for example, are produced with a low or high pre-tonic vowel in order to harmonize to the stressed vowel (see productions in (9) above). The only word that does not follow the same pattern is /pi.ru'litu/ 'pirulito'/'lolypoppy', produced as [pi.i'i. tu]. Our hypothesis is that the child is applying here a process of harmony: having adjacent high vowels on both sides, A. produces the high front vowel instead of the high back vowel. And in 'estrelinha', A. makes use of $[\varepsilon]$, a vowel that does not exist in the pre-tonic subsystem, without any apparent reason (such as an assimilation to an adjacent vowel), but maintains the same place of articulation as the correct vowel/e/. 
Two facts draw our attention in Am. data: vowel /u/ is not acquired before 3;5, the last age analyzed for this child. In addition, the order of acquisition is different in the two positions (stressed: $\mathrm{a}>\mathrm{e}>\mathrm{o}>\mathrm{i}>\mathrm{u}>\mathrm{o}>\varepsilon$; pre-tonic: $\mathrm{a}>\mathrm{o}>\mathrm{i}>\mathrm{e}$ ). The same time difference between the acquisition of the stressed and the pre-tonic found in child A. is also found in child Am. As shown in the data quantity row, Am. has a very small vocabulary (whereas child A. produces more than 100 different words at $1 ; 10$ and child $\mathrm{L}$. produces this quantity at $2 ; 0, \mathrm{Am}$. only reaches this quantity at $3 ; 2$. However, Am. is the child who makes the least substitutions. Am. replaces /a/ by $[\mathrm{u}]$ and $[\mathrm{e}]$, each one in a type. Vowel /o/ is replaced by $[\mathrm{u}]$ in some words, and /e/ is replaced by [i] in a single word. In (10) we have the pre-tonic substitutions found in child Am.'s data.

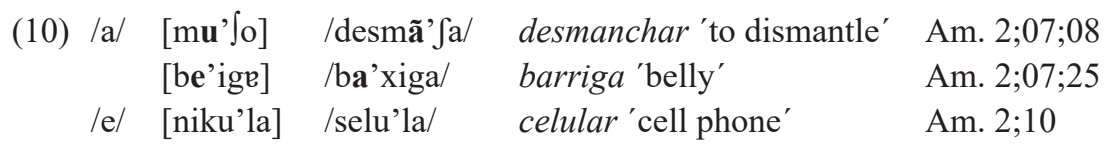

It is worth noting the substitution of /a/ for [u, e], vowels with different places of articulation, at the same age $(2 ; 7)$, and after /a/ being considered frequent in her speech. However, note that in barriga 'belly', we have /a/-raising, partially assimilating to the stressed vowel. In desmanchar 'to dismantle', our hypothesis is that the labiality of $/ \mathrm{m} /$ has affected vowel /a/ - specifically, the [labial] feature was assimilated by the vowel.

Finally, child L. also acquires pre-tonic vowels in a different order when compared to the stressed vowels (stress: $a>i>e, o>\varepsilon, o>u$; pre-tonic: $a>i, o>u>e$ ). Similarly to child A., L. acquires, within the period analyzed, all the vowels that fill this position in BP, and similarly to child Am., the order of acquisition in stressed position is different from pre-tonic position. For both Am. and L., the last vowel to be acquired is /e/. Examples of production by L. are found in (11).

\begin{tabular}{|c|c|c|c|c|}
\hline 1) $/ \mathrm{a} /$ & {$\left[\mathrm{se}^{\prime} \mathrm{pe}^{\mathrm{w}}\right]$} & $/ \mathrm{a}^{\prime} \mathrm{p} \varepsilon \mathrm{v}$ & chapéu 'hat' & L. $1 ; 11 ; 23$ \\
\hline & [se'mi $\left.{ }^{\mathrm{w}}\right]$ & /su'miw/ & sumiu 'disappeared' & L. $2 ; 0 ; 28$ \\
\hline & {$\left[\mathrm{si}^{\prime} \mathrm{bi}^{\mathrm{w}}\right]$} & /su’biw/ & subiu 'climb-past' & L. $2 ; 0 ; 28$ \\
\hline /e/ & [a.le'fa.di] & /ele'fãte/ & elefante 'elephant' & L. $1 ; 11 ; 16$ \\
\hline & [i.'`ey] & /fe' Jey/ & fechei 'closed' & L. $1 ; 11 ; 02$ \\
\hline /i/ & [bũ:'ka] & /bi'ka/ & brincar 'to play' & L. $2 ; 0 ; 14$ \\
\hline & {$\left[\mathrm{d} \mathbf{e}^{\prime} \mathrm{g} \varepsilon^{\mathrm{w}}\right]$} & /mi'gew/ & Miguel (proper name) & L. $1 ; 11 ; 23$ \\
\hline /o/ & [bu'to] & /bo’tow/ & botou 'put-past' & L. $2 ; 7 ; 8$ \\
\hline
\end{tabular}

Table 9 below summarizes the order of acquisition of the segments in the stressed and pre-tonic positions for the three children in this study: 
Table 8 - Summary of the order of vowel acquisition

\begin{tabular}{|c|l|l|}
\hline Child & Context & Order of acquisition \\
\hline \multirow{2}{*}{ A. } & Stressed & $\mathrm{a}, \mathrm{o}>\mathrm{i}, \mathrm{e}, \mathrm{u}>\mathrm{o}>\varepsilon$ \\
\cline { 2 - 3 } & Pre-tonic & $\mathrm{a}>\mathrm{o}>\mathrm{i}>\mathrm{e}>\mathrm{u}$ \\
\hline \multirow{2}{*}{ Am. } & Stressed & $\mathrm{a}>\mathrm{e}>\mathrm{o}>\mathrm{i}>\mathrm{u}, \mathrm{o}>\varepsilon$ \\
\cline { 2 - 3 } & Pre-tonic & $\mathrm{a}>\mathrm{o}>\mathrm{i}>\mathrm{e}$ \\
\hline \multirow{2}{*}{ L. } & Stressed & $\mathrm{a}>\mathrm{i}>\mathrm{e}, \mathrm{o}>\varepsilon, \mathrm{o}>\mathrm{u}$ \\
\cline { 2 - 3 } & Pre-tonic & $\mathrm{a}>\mathrm{i}, \mathrm{o}>\mathrm{u}>\mathrm{e}$ \\
\hline
\end{tabular}

Source: Adapted from Bohn (2015, p.111-137).

\section{Discussion}

Jakobson (1968 [1941]) proposes that vowel acquisition starts with the low vowel contrasting with the high vowels (/a, i, u/). Rangel (2002)'s and Miranda and Matzenauer (2009)'s analysis of stressed vowels indicate the same order of acquisition of stressed and pre-tonic vowels. Bonilha (2004) points out that, in the first stage, the child analyzed in her study had already acquired /e, i, o, u/. The studies on the acquisition of pre-tonic vowels, specifically, draw our attention to phonological processes that cause instability of the vowels in these positions (eg. MATZENAUER, 2009; MIRANDA, 2013; VOGELEY, 2011), but also point to a single acquisition path: low and high vowels, followed by mid vowels (high or low, depending on the dialect).

As could be seen, none of the three children analyzed in our study followed this pattern, either because they have inverted the order of acquisition (for example, child Am. acquired the mid high vowels before the high vowels) or because different vowels were acquired simultaneously, as was the case of child A., who has acquired /i, u/ at the same time as /e/).

In order to explain these results, the first hypothesis to be considered is that children build different hierarchies for stressed and pre-tonic vowels. The main consequence of this hypothesis is that it cannot be said that the pre-tonic system is a subsystem of the stressed vowels, generated by neutralization of the mid vowels - the most accepted analysis for the description of BP vowels (cf. CÂMARA JR., 1977; WETZELS, 1992, among numerous others). Following this hypothesis, it should be expected to find different orders of acquisiton for stressed and pre-tonic vowels and different substitutions, as feature hierarchies could be organized differently. However, although for two children (Am. and L.) the order was different, we found that most substitution patterns are those that also appear in the stressed position.

The alternative hypothesis is that there is a single structure constructed by the child, regardless of the position the vowel occupies in the word. Tables 10, 11 and 12 indicate which vowels had already been acquired in stressed position and what the feature hierarchy for stressed vowels was when pre-tonic vowels were being acquired (according to Bohn, 2015). 
Table 9 - Acquisition of stressed and pre-tonic vowels and hierarchical structure $-\mathrm{A}$.

\begin{tabular}{|c|c|c|c|}
\hline A. & Pre-tonic: & Stressed & Hierarchy (stressed vowels) \\
\hline $1 ; 6$ & $\mathrm{a}$ & $\mathrm{a}, \mathrm{o}$ & Stage 1: $\quad$ low $]$ [non-low $]$ \\
\hline $1 ; 7$ & o & $\mathrm{a}, \mathrm{o}$ & Stage 1: [low $]$ [non-low $]$ \\
\hline $1 ; 8$ & $\mathrm{i}$ & $\mathrm{a}, \mathrm{o}, \mathrm{e}, \mathrm{i}, \mathrm{u}$ & $\begin{array}{ll}\text { Stage 2: } & {[\text { low }][\text { non-low }]} \\
& [\text { back }] \text { non-back }] \\
& {[\text { high }][\text { non-high }]}\end{array}$ \\
\hline $2 ; 0$ & $\mathrm{e}$ & $\mathrm{a}, \mathrm{o}, \mathrm{e}, \mathrm{i}, \mathrm{u}, \mathrm{\jmath}, \varepsilon$ & $\begin{array}{ll}\text { Stage 3: } & {[\text { low }][\text { non-low }]} \\
& {[\text { back }][\text { non-back }]} \\
& {[\text { high }][\text { non-high }]} \\
& {[\text { ATR }][\text { non-ATR }]}\end{array}$ \\
\hline $2 ; 1$ & $\mathrm{u}$ & $\mathrm{a}, \mathrm{o}, \mathrm{e}, \mathrm{i}, \mathrm{u}, \mathrm{\rho}, \varepsilon$ & $\begin{array}{ll}\text { Stage 3: } & {[\text { low }][\text { non-low }]} \\
& {[\text { back }][\text { non-back }]} \\
& {[\text { high }][\text { non-high }]} \\
& {[\text { ATR }][\text { non-ATR }]}\end{array}$ \\
\hline
\end{tabular}

Source: Adapted from Bohn (2015, p.152-162).

Table 10 - Acquistion of stressed and pre-tonic vowels and hierarchical structure $-\mathrm{Am}^{7}$

\begin{tabular}{|c|c|c|c|c|}
\hline Am. & Pre-tonic & Stressed & \multicolumn{2}{|c|}{ Hierarchy (stressed vowels) } \\
\hline $1 ; 11$ & $\mathrm{a}$ & $\mathrm{a}, \mathrm{e}$ & Stage 2: & [back] [non-back] \\
\hline $2 ; 8$ & o & $\mathrm{a}, \mathrm{e}, \mathrm{o}, \mathrm{i}$ & Stage 4: & $\begin{array}{l}\text { [back] [non-back] } \\
{[\text { low }][\text { non-low }]} \\
{[\text { high }][\text { non-high }]}\end{array}$ \\
\hline $2 ; 11$ & $\mathrm{i}$ & $\mathrm{a}, \mathrm{e}, \mathrm{o}, \mathrm{i}$ & Stage 4: & $\begin{array}{l}{[\text { back }][\text { non-back }]} \\
{[\text { low }][\text { non-low }]} \\
{[\text { high }][\text { non-high }]}\end{array}$ \\
\hline $3 ; 2$ & $\mathrm{e}$ & $\mathrm{a}, \mathrm{e}, \mathrm{o}, \mathrm{i}, \mathrm{u}, \varepsilon, \mathrm{\jmath}$ & Stage 5: & $\begin{array}{l}\text { [back] [non-back] } \\
{[\text { low }][\text { non-low] }} \\
{[\text { high }][\text { non-high }]} \\
{[\text { ATR }][\text { non-ATR }]}\end{array}$ \\
\hline
\end{tabular}

Source: Adapted from Bohn (2015, p.162-173).

\footnotetext{
Up to $3 ; 5$, the vowel /u/ had not been frequently produced in the pre-tonic position by Am.
} 
Table 11 - Acquistion of stressed and pre-tonic vowels and hierarchical structure - L.

\begin{tabular}{|c|c|c|c|}
\hline L. & Pre-tonic & Stressed: & Hierarchy (stressed vowels) \\
\hline $1 ; 6$ & $\mathrm{a}$ & $\mathrm{a}, \mathrm{i}$ & Stage 2: [back] [non-back] \\
\hline $1 ; 11$ & $0, \mathrm{i}$ & $\mathrm{a}, \mathrm{i}, \mathrm{e}, \mathrm{o}, \mathrm{\rho}, \varepsilon, \mathrm{u}$ & \begin{tabular}{|ll} 
Stage 6: & {$[$ back $][$ non-back $]$} \\
& {$[$ low $][$ non-low $]$} \\
& {$[$ high $][$ non-high $]$} \\
& {$[$ ATR $][$ non-ATR $]$} \\
\end{tabular} \\
\hline $2 ; 0$ & $\mathrm{u}$ & $\mathrm{a}, \mathrm{i}, \mathrm{e}, \mathrm{o}, \supset, \varepsilon, \mathrm{u}$ & \begin{tabular}{|ll} 
Stage 8: & {$[$ back $][$ non-back $]$} \\
& {$[$ low $][$ non-low $]$} \\
& {$[$ high $][$ non-high $]$} \\
& {$[$ ATR $][$ non-ATR $]$} \\
\end{tabular} \\
\hline $2 ; 7$ & $\mathrm{e}$ & $\mathrm{a}, \mathrm{i}, \mathrm{e}, \mathrm{o}, \mathrm{\rho}, \varepsilon, \mathrm{u}$ & $\begin{aligned} & \text { Stage 8: } {[\text { back }] \text { [non-back }] } \\
& {[\text { low }][\text { non-low }] } \\
& {[\text { high }][\text { non-high }] } \\
& {[\text { ATR }][\text { non-ATR }] } \\
&\end{aligned}$ \\
\hline
\end{tabular}

Source: Adapted from Bohn (2015, p.174-190).

As can be seen in Tables 10, 11 and 12, when pre-tonic vowels emerged, children already had the same vowel in the stressed position. Therefore, the structure they had built for the stressed position at the moment of acquisition of the pre-tonic also captures the acquired pre-tonic vowel. For example, when child Am. acquires the pre-tonic /o/ at 2;8, a hierarchical structure for stressed /o/ with the feature [back, low, high] had already been constructed and allows this vowel's production in pre-tonic position. We did not find any cases in the children's data in which the acquired pre-tonic vowel could not be produced taking into account the hierarchical structure of the stressed vowels at that moment of acquisition.

The hypothesis that there is a single hierarchy that captures the vowel neutralization of BP, but leads to several questions in the context of language acquisition: why do vowels in the pre-tonic position appear later and not at the same time as the stressed vowels? If there is a single hierarchy, how to explain the different order of acquisition often attested to in the data? And finally, what governs the order of acquisition of pretonic vowels?

As we have seen, from the first moment of analysis, at 1;4, children were already able to produce pre-tonic syllables, an aspect already pointed out by Santos $(2005,2007)$, which means that at an early stage they have the syllabic position where unstressed vowels are produced. However, studies of various aspects of phonological acquisition also point to the higher prosodic salience of stressed syllables. The studies in Lamprecht (2004) show that the stressed syllable is a facilitator for the correct production of the segments (vowel and consonant), and that complex syllables (either with branching rhymes or branching onsets) are first correctly produced in the stressed position. In addition, we can observe that the stressed syllables are the locus of greater stability for 
the production of vowels, as has already been suggested by Rangel (2002). Miranda, in her study, points to what is at the heart of the CHT: "This [mid vowels being stable in stressed position and unstable in pre-tonic position] indicate that segments are acquired based on how they behave in the system and not as a single unit of a set." (MIRANDA, 2013, p.94) ${ }^{8}$.

In other words, Miranda claims that the only reason for the later acquisition of the vowels in pre-tonic position is vowel instability in this position, a result of the processes that affect these vowels, a position shared by Bohn (2015).

Let us see how Miranda's proposal would work. According to Wetzels (1992), BP has phonological processes that affect only vowels in unstressed syllables (neutralization in the pre-tonic position, neutralization of non-final pos-tonic vowels, neutralization of the final pos-tonic vowels, and vowel harmony); processes that affect only vowels in stressed syllables (datilyc lowering, spondaic lowering, mid-vowel lowering in verb roots, neutralization by occlusive adjustment in coda); and a process that affects vowels regardless of their stress (nasal neutralization).

Wetzels (1992) suggests a nasal neutralization process that explains why, in nasal-closed syllables, only mid-high vowels emerge (e.g/'õn.xa/ 'honra'/ honor' and /'o.ra/ ' 'hora'/'hour'). However, children have no evidence that this is a process of neutralization (between low and mid-high vowels), and nothing would prevent them from processing this information as a gap in the system.

Cases affecting stressed vowels are also instigating from the acquisition point of view. Coda occlusive neutralization shows cases in which syllables closed by a nonsonorant stop are always produced as mid-low vowels (e.g ['sck.so] 'sexo'/ 'sex', [i'noks] 'inox'/ 'stainless steel'). However, children have no evidence that there is neutralization between mid vowels in this position. On the contrary, children are exposed to the fact that these vowels, when in pre-tonic syllables, become mid-high, following the rule of neutralization of the pre-tonic position ([sek'sista] 'sexista'/ 'sexist', [i.nok.si'da.vew] 'inoxidável' / 'stainless steel-adj'). The spondaic lowering process shows that in words with an exceptional stress pattern (paroxitons with a heavy final syllable) the mid vowel is always produced as mid-low ([re'porter] 'repórter'/ 'reporter', ['sc.zar] 'César'/ 'Ceasar'). However, this rule has many exceptions (for example, the rule is blocked when the syllabic weight is generated by a inflectional suffix (['tes.til] 'textil' / 'textile') and children are exposed only to the neutralization of the pre-tonic vowel (eg [xepor'tazẽj] 'reportagem' / 'news report', [se'zarja] 'cesárea' / 'cesarean (c-cut)'). Datylic lowering shows that the mid vowels in proparoxytone position are always produced as mid-low ([eske'leto] 'esqueleto' / 'skeleton'> [eske'le.tiko] 'esquelético' / 'skeletal'). Finally, verbal root lowering captures the fact that in verbal forms the mid-low vowel always occurs, whereas in the noun form both a mid-low and a mid-high vowel can occur (['for.sa] 'força' /

"Isso [vogais médias são estáveis na posição tônica e instáveis na posição pretônica] parece apontar para a ideia de que os segmentos são adquiridos com base no funcionamento do sistema e não como simples unidade de um conjunto." (MIRANDA, 2013, p.94). 
'force-noun' vs. ['for.sa] 'força' / 'force-verb-imp', [a'pelo] 'apelo' / 'appeal-noun' vs. [a'pelo] 'apelo' / 'appeal-verb- 1sg. present'.

Common to almost all of the processes described above (except for the dactylic lowering and verbal lowering) is the fact that the child is not exposed to alternate forms, but to a single form. It is only by comparing several vocabulary items that one can infer that there is a phonological process being applied - which would explain the absence of a given phoneme in one position. In short, in the stressed position, children have no evidence that vowel neutralization occurs.

The phonological processes in unstressed syllables behave differently. In all of them the child has clues that there is a process of neutralization either because it is an optional process (such as Vowel Harmony - e.g. p[e]rigo p[i]rigo 'perigo' / 'danger'), or because derived words show an alternation (e.g. $p[\varepsilon] l e$ 'pele'/ 'skin' > p[e]lado 'pelado'/'naked', for the neutralization of the pre-tonic; ['kaxひ] 'carro'/'car' > [kaxose'ria] 'carroceria'/ 'wagon', for the neutralization of the final unstressed vowel; núm[e]ro núm[i]ro 'número' / 'number' for non-final pos-tonic neutralization). Thus, it can be said that the vowel system is more stable in the stressed position than in the pre-tonic position. The alternations are clues, for the children, that it is one vowel system, but it might take longer to establish which vowel is the underlying representation in unstressed position when compared to the stressed position, where there is no alternation. In short, at the same time that the phonological processes provide evidence for the pre-tonic and its relation to the stressed system, the alternations also make the acquisiton of the vowels in this position more difficult and consequently take more time.

Considering the data in this study, we have shown that for all the children analyzed, vowel /a/ was the first to be acquired. In adult speech, in the pre-tonic position, vowel /a/ does not undergo neutralization, it is the most stable of all the vowels in this position; its early acquisition, then, confirms Miranda (2013)'s and Bohn (2015)'s analyses. However, the next vowels to be acquired are all subject to neutralization in adult speech: $/ \varepsilon, \mathrm{e} /$ and $/ \mathrm{J}, \mathrm{o} / \mathrm{by}$ neutralization of the pre-tonic position, /e, $\mathrm{i} /$ and /o, u/ by vowel harmony. Regarding these vowels, Miranda (2013) follows Jakobson (1968 [1941]), for whom the acquisition will follow the same pattern as in the stressed position: initially the high vowels and then the mid-vowels. Bohn (2015)'s results do not follow this order, however (cf. Table 9). Bohn points out that, in adult language, phonological processes do not affect front and back vowels the same way, and assumes that the child is sensitive to differences in how this phonological process is applied in adult speech. She exemplies her reasoning with vowel harmony: according to Callou, Moraes and Leite (2002), Viegas (2001), Yacovenco (1993) and Casagrande (2004), vowel harmony affects vowel /e/ much more often than /o/, which leads these authors to propose that only /e/ undergoes the process in BP, and that the cases in which /o/ is raised to $[\mathrm{u}]$ are phonetically motivated. As /e/ undergoes more processes than /o/, it is a more unstable vowel, and that is why, according to Bohn, this phoneme would be the last to be acquired in the pre-tonic position. 
However, if Bohn's analysis explains why /e/ is acquired later, it does not explain why there is an asymmetry in acquisition: why does the child acquire /i, o/ and not /i, $\mathrm{u} /$ ? That is, if we assume instability affects acquisition, with no changes in the hierarchical structure of the vowels and no other factor influencing the process, we should expect children to follow the path proposed by Miranda: $\mathrm{a}>\ldots>\mathrm{o}>\mathrm{e}$ (where ... indicates a possible ordering between $/ \mathrm{i} /$ and $/ \mathrm{u} /$ depending on one being more unstable than the other). However, that is not what Bohn's results show. For the three children, in the pre-tonic position, after the low vowel /a/ children acquired a high and mid vowel (simultaneously or with little temporal difference).

According to Jakobson's proposal, vowel acquisition depends on contrast: low > high $>$ mid. CHT proposes that the internal structure of the segments is built following feature contrasts (DRESHER, 2009), but it does not explain how contrasts are acquired. Bohn (2015) applies CHT to observe if this theory can explain the acquisition data and proposes that it is possible to have evidence of the construction of the hierarchies through the substitutions found in the data: if the vowels [o, u, a] alternate, it is because at that moment they share the same feature and do not contrast. Our proposal here is that the child deals with two variables: a principle of maximum contrast (inspired by the notion of contrast proposed by CHT) and the segments instability in the input (as pointed out by Miranda 2013, among others). According to CHT, only contrastive features are acquired. We propose that there should be a Principle of Contrast that governs the order of acquisition of segments. Looking at our data, this means that the child, when acquiring the pre-tonic position, selects, within the hierarchy, which has already been constructed, which segments are more contrastive. For example, child L., at age 1;6, has only vowel /a/ in the hierarchy (evidenced in the stressed position), and it is this only vowel that it also produced in the pre-tonic position. At 1;10, L. also starts producing / i, o/ in pre-tonic position when she already produces /a, i, e, o/ in stressed position. The question we pose is: why does the child select/i/ and not/e/? The first part of our answer to this question concerns the Contrast Principle in its maximum version (which we will call the Principle of Maximum Contrast): if the child selects /o, e/ or $/ \mathrm{i}, \mathrm{u} /$, these pairs of segments are contrastive, but not maximally contrastive. Observe that / i, $\mathrm{u} /$ are maximally contrastive with respect to /a/ - they show a maximum contrast of height and place -, but they contrast in place only, as they are both high vowels. ${ }^{9}$ If the child selects /o, e/ we have the same contrast problem: they contrast with respect to place only, and a smaller contrast is established in relation to /a/ (as now, instead of high vs. low vowels, we have a mid-high vs. low vowel).

On the other hand, if the child selects /e, $\mathrm{u} /$ or / i, o/, the contrast is now greater: in both cases, vowels contrast with respect to place and height. The child would then have three levels of height in the pre-tonic position: /a/ (low), /o/ (mid-high) and /i/ (high). We emphasize that this does not mean that the child has created an asymmetric system, because the system is the same as in the stressed position, where the seven

One might argue that these vowels also contrast phonetically in roundness. However, roundness is not contrastive in BP. 
vowels have already been acquired. In the pre-tonic position, there are three groups of vowel: /a; i, o; e, u/, regardless of whether the hierarchy of vowel phonemes starts with place (as is the case of Am. and L.) or with height (as is the case of A.).

In summary, the data on the acquisition of pre-tonic vowels indicate that the child treats pre-tonic vowels and stressed vowels the same way; that is, they have the same internal feature hierarchy. Still, the acquisition order is different. Our proposal is that this order of acquisition in the pre-tonic position is affected by the instability of some vowels and by a principle of maximum contrast. The notion of contrast assumed by CHT is responsible for the selection of contrastive features. The Contrast Principle in its maximum version governs the order of acquisition: given the contrastive features, the segments tend to emerge by contrasting maximally (in the greatest number of features).

Finally, one might wonder why the Principle of Maximum Contrast is not applied in the acquisition of the stressed vowels. As we have seen, in the stressed position we have the emergence of vowels of the same height: for A., /i, u/ are acquired at the same time, L. acquires /e, o/ at the same time; Am. acquires /o/ and soon after /e/. The difference between the two systems is that the stressed system is more stable, with vowel contrasts more easily to be distinguished. Thus, the Principle of Contrast would apply, but without the need to be in the greatest possible number of contrasts (Principle of Contrast Maximum).

\section{Final considerations}

In this article, we discuss the acquisition of vowels taking into account the fact that different children have different orders of acquisition of the segments. As we have seen, theories that assume a universal hierarchy cannot account for this variability. We assume, then, that while the notion of hierarchy is innate, the organization of feature in the hierarchy is constructed - as proposed by CHT (DRESHER, 2009).

Our objective is to discuss whether the acquisition of pre-tonic vowels is different from the acquisition of stressed vowels. To this end, we revised Bohn (2015)'s data. The author assumes Miranda (2013), who claims that the acquisition of the segments in the pre-tonic position is subject to the instability affecting these vowels. Thus, vowel /e/, for example, would be acquired after /o/ because /e/ is more subject to phonological processes in this position. We argue that instability contributes to the organization of vowels, but it should not be the only explanation, as, if taken to its ultimate consequences, it would predict that the emergence of vowels in the pre-tonic position would be: /a/ > / , u/ > /e, o/. However, the data from the three children analyzed indicate that the high vowels are not acquired simultaneously, but combined with the mid-vowels (initially /i, o/ and then /e, u/). Thus, we propose that in addition to the instability, there is a Principle of Maximum Contrast that guides the acquisition of pretonic vowels in BP. According to this principle, segments with less prosodic salience, such as the pre-tonic subsystem discussed in this study, should be maximally contrastive to be acquired. In this sense, the order of acquisition is not governed by the notion of 
contrasts, but by maximum contrasts, which, for pre-tonic vowels in $\mathrm{PB}$, result from the opposition between both height and place. In addition, the results indicate that the child is sensitive to the phonological processes very early as it influences the acquisition of the segmental layer. Since vowel /e/ is very unstable because of the processes it undergoes, the child will first acquire the mid vowel /o/. The Principle of Maximum Contrast will direct the child to acquire a vowel which maximally contrasts with /o/, that is $/ \mathrm{i} /$. Our hypothesis is that this principle only applies in contexts of neutralization or less prosodic saliency of the segments, which explains why we do not find its effects in the stress position. A possible verification of this hypothesis may come from studies in which the acquisition of other unstressed positions are conducted (i.e. the non-final pos-tonic and the final pos-tonic).

\section{Acknowledgments}

We thank Elan Dresher, the audience from ENAL 2016 and the two anonymous reviewers for the comments and discussion of the text and we exempt them from all remaining problems.

The author thanks the PhD grant from the Department of Linguistics of the FFLCH / USP (CAPES Proex 2013-2015) and the PDSE / CAPES scholarship at the University of Toronto (\# 14506 / 13-0)

This author thanks CNPq for its financial support (grant 305524 / 2012-7) for this research.

BOHN, G.; SANTOS, R. A aquisição de vogais pretônicas em Português Brasileiro. Alfa, São Paulo, v.62, n.1, p.191-221, 2018.

- RESUMO: O artigo discute a aquisição de vogais pretônicas em português brasileiro, por 3 crianças monolíngues adquirindo o dialeto paulista, com idade entre 1;4 e 3;5, e sua relação com a aquisição das vogais no ambiente tônico. Com base em Miranda (2013), partimos do pressuposto de que a aquisição das vogais pretônicas está sujeita à instabilidade desse subsistema, e, portanto, segmentos afetados por processos fonológicos seriam adquiridos mais tardiamente nessa posição. As produções mostram que as vogais altas pretônicas são adquiridas em contraste com as vogais médias, (/i,o/ e le,u/), sendo a pretônica /o/ adquirida antes de le/. Analisamos nossos resultados à luz da Hierarquia Contrastiva de Traços (DRESHER, 2009), para a qual a representação lexical dos segmentos é especifica de cada língua, trazendo somente os traços contrastivos e ativos em processos fonológicos naquele sistema, e propomos que a aquisição da pauta pretônica é regida por um Princípio de Contraste Máximo: devido a instabilidade dessa posição, os segmentos devem ser maximamente contrastivos, ou seja, por ponto e altura vocálica. A pretônica /el, por ser a mais instável (cf. CALLOU; MORAES; LEITE, 2002, VIEGAS, 2001 e YACOVENCO, 1993), é a última a ser adquirida, trazendo consigo a pretônica $/ u /$.

- PALAVRAS-CHAVE: Aquisição fonológica. Contraste fonológico. Vogal pretônica. 


\section{REFERENCES}

BISOL, L. Sândi externo: o processo e a variação. In: KATO, M. (Org.). Gramática do Português Falado. v. 5. Campinas: Ed. da UNICAMP, 1996. p.55-96.

BOHN, G. P. Aquisição das vogais tônicas e pretônicas do português brasileiro. 2015. 218 f. Tese (Doutorado em Linguística) - Faculdade de Filosofia, Letras e Ciências Humanas, Universidade de São Paulo, São Paulo, 2015.

BONILHA, G. F. G. Aquisição fonológica do português brasileiro: uma abordagem conexionista da Teoria da Otimidade. 2004. 389 f. Tese (Doutorado em Letras) Faculdade de Letras, Pontifícia Universidade Católica do Rio Grande do Sul, Porto Alegre, 2004.

CALLOU, D.; MORAES, J.; LEITE, Y. A elevação das vogais pretônicas no português do Brasil: processo(s) de variação estável. Letras de Hoje, Porto Alegre: EDIPUCRS, v.37, n.1, p.9-24, 2002.

CÂMARA Jr., J. M. Para o estudo da fonêmica portuguesa. 2. ed. Rio de Janeiro: Padrão, 1977.

CASAGRANDE, G. P. B. Harmonização vocálica: análise variacionista em tempo real. 2004. 171 f. Dissertação (Mestrado em Letras) - Faculdade de Letras, Pontifícia Universidade Católica do Rio Grande do Sul, Porto Alegre, 2004.

CHERRY, E..; HALLE, M.; JAKOBSON, R. Toward the logical description of languages in their phonemic aspect. Language, v.29, p.34-46, 1953.

CLEMENTS, N.; HUME, E. The internal organization of speech sounds. In: GOLDSMITH, J. (Org.). The handbook of phonological theory. Oxford: Blackwell, 1995. p.245-306.

DRESHER, B. E. The Contrastive Hierarchy in Phonology. Cambridge: Cambridge University Press, 2009.

. The arch not the stones: universal feature theory without universal features.

Nordlyd, University of Tromso, Noruega, n.41, p.165-181, 2015.

FEE, E. J. Underspecification, Parameters, and the Acquisition of Vowels. 1991. 489 f. PhD (Dissertation) - University of British Columbia, 1991.

HALL, D. C. The role and representation of contrast in phonological theory 2007. 293 f. Tese (Doutorado) - University of Toronto, Toronto, 2007.

HALLE, M. The sound pattern of Russian: a linguistes and acoustical investigation. Second Printing. The Hague: Mouton, 1971[1959].

INGRAM, D. Procedures for the Phonological Analysis of Children's Language. Baltimore: University Park Press, 1981. 
. First Language Acquisition: Method, Description, and Explanation.

Cambridge: Cambridge University Press, 1989.

JAKOBSON, R. Child Language, Aphasia and Linguistic Universals. The Hague: Mouton. 1968[1941].

LAMPRECHT, R.; BONILHA, G.; FREITAS, G.; MATZENAUER, C.; MEZZOMO, C.; OLIVEIRA, C.; RIBAS, L. Aquisição fonológica do português: perfil de desenvolvimento e subsidies para terapia. Porto Alegre: Artmed, 2004.

LEE, S. H. Contraste das Vogais no PB. Portuguese-Brazilian Studies, v.5, p.201221, 2008.

MACKEN, M. A. Developmental reorganization of phonology: a hierarchy of basic units of acquisition. Lingua, v.49, n.1, p.11-49, 1979.

MACKENZIE, S. Contrast and Similarity in Consonant Harmony Processes. 2009. 226 f. Tese (Doutorado em Linguística) - Universidade de Toronto, Toronto, 2009.

MATZENAUER, C. L. B. Sobre as vogais médias pretônicas na aquisição do português brasileiro. Revista Organon, Porto Alegre: Universidade Federal do Rio Grande do Sul, n.46, p.71-108, 2009.

MIRANDA, A. R. Insights sobre a representação das vogais pretônicas no Português do Brasil: dados de Desenvolvimento Fonológico e de escrita inicial. Revista Organon, Porto Alegre: Universidade Federal do Rio Grande do Sul, v.28, n.54, p.83-100, jan./ jun. 2013.

MIRANDA, A. R.; MATZENAUER, A. R. Traços distintivos e a aquisição das vogais do PB. In: HORA, D. (Org.). Vogais no ponto mais oriental das Américas. João Pessoa: Idéia/UFPB, 2009.

NOGUEIRA, M. V. Aspectos segmentais no processo de sândi externo no falar de São Paulo. 2007. 154 f. Dissertação (Mestrado em Linguística) - Faculdade de Filosofia, Letras e Ciências Humanas, Universidade de São Paulo, São Paulo, 2007.

PYE, C.; INGRAM, D.; LIST, H. A comparison of initial consonant acquisition in English and Quiché. In: NELSON, K.; KLEECK, A. Van (Org.). Children's Language. Hillsdale, NJ: Lawrence Erlbaum Associates. 1987. p.175-190.

RANGEL, G. A. Aquisição do Sistema Vocálico do Português Brasileiro. 2002. 170 f. Tese (Doutorado em Letras) - Faculdade de Letras, Pontifícia Universidade Católica do Rio Grande do Sul, Porto Alegre, 2002.

SANTOS, R. S. Projeto de Aquisição do Ritmo em Português Brasileiro. FAPESP. 2003/13565-4, 2005. 
. A aquisição prosódica do português brasileiro de 1 a 3 anos: padrões de palavra e processos de sândi externo. 2007. Tese (Livre-docência) - Faculdade de Filosofia, Letras e Ciências Humanas, Universidade de São Paulo, São Paulo, 2007.

SILVA, C. C. Aquisição da regra de assimilação de vozeamento em Português Brasileiro. 2008. 161 f. Dissertação (Mestrado em Linguística) - Faculdade de Filosofia, Ciências Humanas e Letras, Universidade de São Paulo, São Paulo, 2008.

VIEGAS, M. C. O alçamento de vogais médias pretônicas e os itens lexicais. 2001. 170 f. Tese (Doutorado em Linguística) - Faculdade de Letras, Universidade Federal de Minas Gerais, Belo Horizonte, 2001.

VIHMAN, M. et al. Phonological development from babbling to speech: common tendencies and individual diferences. Applied Psycholinguistics, n.7, p.3-40, 1986.

VOGELEY, A. C. S. Vogais médias pretônicas: aquisição e variação. 2011. 236 f. Tese (Doutorado em Linguística) -Centro de Ciências Humanas, Letras e Artes, Universidade Federal da Paraíba, João Pessoa, 2011.

VOGELEY, A. C.; HORA, D. Aquisição das vogais médias pretônicas. In: XV Congresso Internacional de la ALFAL, 2008, Montevideo. Livro de Resúmenes - XV Congresso Internacional de la ALFAL. Montevideo: Gega s.r.1., 2008. p.150.

WETZELS, L. M. Mid-vowel alternations in the Brazilian Portuguese. Cadernos de Estudos Linguísticos, Campinas: Universidade Estadual de Campinas, v.23, p.19-55, 1992.

YACOVENCO L. C. As vogais médias pretônicas no falar culto carioca. 1993. 185 f. Dissertação (Mestrado em Língua Portuguesa) - Faculdade de Letras, Universidade Federal do Rio de Janeiro, Rio de Janeiro, 1993.

ZHANG, X. I. Vowel systems of the Manchu-Tungus languages of China. 1996. 252 f. Tese (Doutorado em Linguística) - Universidade de Toronto, Toronto, 1996.

Received in April 3, 2017

Approved in July 30, 2017 
